\title{
A Novel Snake Venom Disintegrin That Inhibits Human Ovarian Cancer Dissemination and Angiogenesis in an Orthotopic Nude Mouse Model
}

\author{
Francis S. Markland ${ }^{a}$ Kate Shieh $^{\mathrm{a}}$ Qing Zhou $^{\mathrm{a}}$ \\ Vladislav Golubkov ${ }^{a}$ Russell P. Sherwin ${ }^{b}$ Valda Richters $^{b}$ \\ Richard Sposto ${ }^{c}$
}

Departments of a Biochemistry and Molecular Biology, bPathology and ${ }^{\mathrm{c}}$ Preventive Medicine, and USC/Norris Comprehensive Cancer Center, University of Southern California,

Keck School of Medicine, Los Angeles, Calif., USA

\section{Key Words}

Ovarian cancer · Adhesion · Invasion • Integrin · Snake venom • Disintegrin . Angiogenesis · Animal model

\begin{abstract}
OVCAR-5 is a human epithelial carcinoma cell line of the ovary, established from the ascitic fluid of a patient with progressive ovarian adenocarcinoma without prior cytotoxic treatment. The unique growth pattern of ovarian carcinoma makes it an ideal model for examining the anticancer activity of contortrostatin (CN), a homodimeric disintegrin from southern copperhead venom. FACS analysis revealed that OVCAR- 5 is integrin $\alpha v \beta 3$ negative, but $\alpha v \beta 5$ positive. $\mathrm{CN}$ effectively blocks the adhesion of OVCAR- 5 cells to several extracellular matrix proteins and inhibits tumor cell invasion through an artifi-
\end{abstract}

\begin{tabular}{ll}
\hline KARGER & ( ) 2002 S. Karger AG, Basel \\
Fax + 4161306 1234-0147/01/0316-0183\$17.50/0 \\
$\begin{array}{l}\text { E-Mail karger@karger.ch } \\
\text { www.karger.com }\end{array}$ & $\begin{array}{l}\text { Accessible online at: } \\
\text { www.karger.com/journals/hae }\end{array}$
\end{tabular}

cial basement membrane. In a xenograft nude mouse model with intraperitoneal introduction of OVCAR-5 cells, intraperitoneal injection of $\mathrm{CN}$ was used for therapy. Tumor dissemination in $\mathrm{CN}$-treated versus control groups was studied by gross examination, and antiangiogenic potential was examined by factor VIII immunohistochemistry and image analysis. CN not only significantly inhibited ovarian cancer dissemination in the nude mouse model, but it also dramatically prevented the recruitment of blood vessels to tumors at secondary sites.

$$
\text { Copyright } \odot 2002 \text { S. Karger AG, Basel }
$$

\section{Introduction}

Disintegrins are small, disulfide-rich, ArgGly-Asp (RGD)-containing peptides from snake venom [1] that bind to cell adhesion 
receptors (integrins) on the surface of normal and malignant cells [2-4]. Disintegrins have been characterized from the venom of many snakes and were originally distinguished by their ability to inhibit platelet aggregation [3, 5]. We have purified and characterized the disintegrin, contortrostatin $(\mathrm{CN})$, from southern copperhead snake venom [6]. $\mathrm{CN}$ gives a single band of approximately $14-15 \mathrm{kD}$ by nonreducing SDS-PAGE and approximately 6-7 $\mathrm{kD}$ by reducing SDS-PAGE. Mass spectrometry indicated a mass of 13,505 for intact $\mathrm{CN}$ and 6,956 for the reduced and pyridylethylated protein, indicating that it is a homodimer, a structure unique among all other disintegrins reported to date. We have determined the primary structure of $\mathrm{CN}$ [7]. In addition to $\alpha \operatorname{IIb} \beta 3$ on blood platelets, integrins $\alpha 5 \beta 1, \alpha v \beta 3$ and $\alpha v \beta 5$ on tumor cells have been shown to be binding sites for $\mathrm{CN}$ [8-10].

Integrins are important cell surface receptors that are involved in cell-cell and cellmatrix interactions [11]. All integrins are $\alpha / \beta$ heterodimeric glycoproteins [12]; different $\alpha$ subunits combine with several distinct $\beta$-subunits resulting in a range of specificity toward distinct extracellular matrix (ECM) proteins [11]. Several classes of integrins recognize the tripeptide RGD sequence present in ECM proteins [13]. Although originally believed to be inert molecules, integrins are known to link the ECM with cytoskeletal proteins and to be involved in bidirectional signaling that alters cellular functions [14].

In previous investigations, we reported that $\mathrm{CN}$ binds to integrins and blocks the adhesion of human breast cancer cells (MDAMB-435) to the ECM [9]. CN also prevents invasion of MDA-MB-435 cells through an artificial basement membrane. Daily local injection of $\mathrm{CN}$ into MDA-MB-435 tumor masses in an orthotopic xenograft nude mouse model significantly inhibits tumor growth and reduces the occurrence of pulmonary metastasis. We have identified $\alpha v \beta 3$, an important integrin mediating cell motility and tumor invasion, as one of the binding sites for CN on MDA-MB-435 cells. We hypothesized that $\mathrm{CN}$ inhibits the progression of breast cancer, at least in part, by an antiangiogenic action, and we have shown in the xenograft nude mouse model that $\mathrm{CN}$ dramatically inhibits breast cancer-induced angiogenesis [9]. In the present study, we report that $\mathrm{CN}$ has effective antitumor activity in vitro and in vivo in a human ovarian cancer cell line, OVCAR-5. Studies about OVCAR-5 utilized a xenograft model established by Hamilton et al. [15]. Immunohistochemistry was used to demonstrate that $\mathrm{CN}$ significantly inhibited angiogenesis in the ovarian cancer animal model.

\section{Materials and Methods}

\section{Materials}

Venom from Agkistrodon contortrix contortrix was purchased from Miami Serpentarium Laboratories (Punta Gorda, Fla., USA). Contortrostatin was purified by four-step high-performance liquid chromatography $[6,8]$. Fibronectin $(\mathrm{FN})$, vitronectin $(\mathrm{VN})$ and Matrigel $^{\mathrm{TM}}$ were from Becton Dickinson (Bedford, Mass., USA). Monoclonal antibodies (mAbs) PID6 (anti- $\alpha 5$ ) and P4C10 (anti- $\beta 1$ ) were purchased from Gibco Life Technologies (Gaithersburg, Md., USA), and P1F6 (anti- $\alpha$ v 35 ) was from Chemicon International (Temecula, Calif., USA). MAb 7E3 (an anti$\alpha I I b \beta 3$ antibody that has a high degree of cross-reactivity to $\alpha v \beta 3$ ) was kindly provided by Dr. Marian Nakada (Centocor, Malvern, Pa., USA). Goat antimouse IgG conjugated with fluorescein isothiocyanate (FITC) was purchased from Jackson ImmunoResearch (West Grove, Pa., USA). The monoclonal rabbit antihuman antibody against factor-VIII-related antigen, goat anti-rabbit secondary antibody, and immunochemistry detection kit (HistoMouse-SP kit) were purchased from Zymed Laboratories, Inc. (Gilroy, Calif., USA). 


\section{Cell Culture}

OVCAR-5 human ovarian carcinoma cell line was generously provided by Dr. Tom Hamilton (Fox Chase Cancer Center, Philadelphia, Pa., USA). OVCAR-5 cells were derived from a patient with advanced epithelial ovarian cancer with no prior cytotoxic therapy [15]. The cells were grown in RPMI with $10 \%$ fetal bovine serum and Premix.

\section{Characterization of Integrin Profile by Flow}

Cytometry

Standard FACS analysis with specific anti-integrin antibodies was employed to detect integrins displayed by OVCAR- 5 cells.

\section{Adhesion of OVCAR-5 Cells to CN and ECM \\ Protein}

The level of cell adhesion supported by different $\mathrm{CN}$ concentrations $(0.1,0.5,1,5 \mu \mathrm{g} / \mathrm{ml})$ was determined experimentally by immobilizing $\mathrm{CN}$ onto Immulon-II 96-well microtiter plates (Dynex Technologies, Inc., Chantilly, Va., USA). Excess protein was washed off and unbound sites were blocked with $1 \%$ bovine serum albumin. OVCAR-5 cells $(100 \mu 1$, $10^{5}$ cells $\left./ \mathrm{ml}\right)$ were seeded in the coated wells $(1 \mathrm{~h}$, $37^{\circ} \mathrm{C}$ ). Unbound cells were washed off with three washings of PBS. Cell adhesion was determined by Cell Titer $96^{\mathrm{TM}} \mathrm{AQ}$ ueous Nonradioactive Cell Proliferation Assay kit (Promega, Madison, Wisc., USA).

VN $(15 \mu \mathrm{g} / \mathrm{ml})$ and FN $(15 \mu \mathrm{g} / \mathrm{ml})$ were immobilized onto Immulon-II 96-well microtiter plates. Unbound sites were blocked with $1 \%$ bovine serum albumin in PBS. OVCAR-5 cells in serum-free medium (SFM) were treated with different concentrations of $\mathrm{CN}(0,1,10,100,1,000 \mathrm{nM})$ for $30 \mathrm{~min}$ at room temperature, added to each well of microtiter plates and treated as described above. All tests were repeated at least three times in triplicate.

\section{Invasion Assay}

Transwells (Costar, Cambridge, Mass., USA) were coated with Matrigel (1:50) in SFM and dried in the hood overnight. Membranes were rehydrated with $500 \mu \mathrm{l}$ of SFM $1 \mathrm{~h}$ before cells were added. Cells were trypsinized, washed in serum-containing medium, and resuspended in SFM. Different concentrations of CN $(0,10,100,1000 \mathrm{n} M)$ were used to treat OVCAR-5 cells ( $30 \mathrm{~min}$ at room temperature). MAbs, anti- $\alpha \mathrm{v} \beta 3$ (7E3) and anti- $\alpha \mathrm{v} \beta 5$ (P1F6), were used separately to treat cells for 30 min before cell suspensions were added to the top chamber; HT1080-conditioned medium $(600 \mu \mathrm{l})$ was in the bottom chamber. Untreated OVCAR-5 cells, with HT1080-conditioned medium in the bottom chamber, was used as a positive control, and untreated OVCAR-5 cells, with SFM in the bottom chamber, was used as a negative control. Plates were incubated for $8 \mathrm{~h}$ to determine the level of cell migration. After incubation, inserts were removed and stained with $0.2 \%$ crystal violet aqueous solution in $20 \%$ methanol for $30 \mathrm{~min}$. After washing, noninvaded cells from the upper surface of the membrane were removed with cotton swabs. Invaded stained cells were dissolved in $250 \mu \mathrm{l}$ of $1 \%$ SDS and $200 \mu \mathrm{l}$ were transferred to a 96-well plate. Optical density at $570 \mathrm{~nm}$ was measured in a microplate reader.

\section{Animal Model}

Five-week-old female nude mice (BALB/c/nu/nu) were purchased from Simonsen Lab (Gilroy, Calif., US). For the humane treatment of experimental animals, a protocol approved by the Institutional Animal Care and Use Committee, University of Southern California, USA, was followed. Animals were kept in a pathogen-free environment, and fed sterilized food and water. OVCAR-5 cells were washed and resuspended in sterile PBS. Cell suspension $\left(10^{6}\right.$ cells/ mouse, $0.2 \mathrm{ml} /$ mouse) was injected into the peritoneal cavity.

The animal study used 22 five-week-old female nude mice. Both the control and treated groups contained 11 mice. Implanted tumors were allowed to grow for 1 week prior to the initiation of treatment. The treated group received twice daily injections of $200 \mu \mathrm{l}$ of $\mathrm{CN}(0.1 \mathrm{mg} / \mathrm{ml}, 40 \mu \mathrm{g} /$ day $)$. The control group received twice daily injections of physiological saline ( $200 \mu 1 /$ injection). Treatment was continued for a total of 4 weeks, at which time the nude mice were anesthetized by inhalation of Metofane (Pitman-Moore, Mundelein, Ill., USA) in a closed chamber and euthanized for angiogenic study. Photographs were taken to document tumor load. Tumor tissue from the peritoneal cavity was collected, weighed, and stored in $4 \%$ formalin at $4{ }^{\circ} \mathrm{C}$ for factor VIII immunohistochemistry.

\section{Microvessel Density Analysis}

Tumor masses from the in vivo study were fixed in phosphate-buffered $10 \%$ formalin, embedded in paraffin, sectioned at $4 \mu \mathrm{m}$, and processed for immunohistochemistry. Slides were prepared for staining by treatment with xylene and a graded alcohol series. Specimens were placed in $3 \% \mathrm{H}_{2} \mathrm{O}_{2}$ to quench endogenous peroxidase activity and treated with citrate buffer. Slides were incubated with $100 \mu$ l of rabbit anti-factor VIII mAb overnight $\left(37^{\circ} \mathrm{C}\right)$, treated with secondary goat anti-rabbit antibody, and developed by the standard peroxidase procedure. 


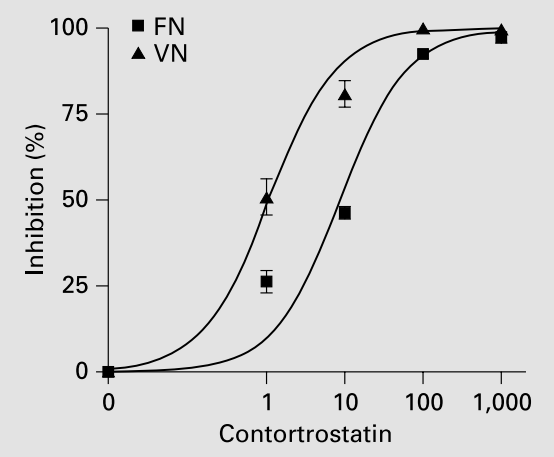

Fig. 1. Inhibition of adhesion of OVCAR-5 cells to immobilized VN and FN. Pretreatment of OVCAR-5 cells with $\mathrm{CN}$ for $30 \min (0-1,000 \mathrm{n} M \mathrm{CN})$ inhibited adhesion of OVCAR- 5 cells $\left(100 \mu \mathrm{l}\right.$ of cells, $10^{5}$ cells/ $\mathrm{ml}$ ) to immobilized ECM proteins following $1 \mathrm{~h}$ of incubation. The $\mathrm{IC}_{50}$ for $\mathrm{CN}$ inhibition of OVCAR-5 adhesion to immobilized VN was $1 \mathrm{n} M$, and to immobilized FN $10 \mathrm{n} M$. CN at similar concentrations did not inhibit adhesion to immobilized laminin or collagen type I.

\section{Image Analysis}

'Hot spots' were selected within each sample slide at 100-fold magnification with a Zeiss light microscope and area measurements (pixels) were made using a Leica Q570 image analyzer. 'Hot spots' are defined as areas of high vessel density $[9,16]$. To reduce bias in this study, analysis of the slides was done in a blind fashion.

\section{Results}

\section{OVCAR-5 Integrin Profile}

Primary mAbs against integrins $\alpha v \beta 3$ (7E3), $\alpha \mathrm{v} \beta 5$ (P1F6), $\alpha 5$ (P1D6), and $\beta 1$ (P4C10) were incubated with OVCAR-5 cells; bound antibodies were detected by secondary FITC-labeled antibody. Flow cytometry results showed that OVCAR-5 cells do not express integrin $\alpha v \beta 3$. This is an interesting result because previous studies have pointed to the importance of this integrin for tumor cell migration $[17,18]$. However, OVCAR-5 cells do express $\alpha v \beta 5, \alpha 5$ and $\beta 1$.

\section{Contortrostatin Inhibits OVCAR-5}

\section{Adhesion to Immobilized ECM Proteins}

OVCAR-5 cells were pretreated with $\mathrm{CN}$ at different concentrations for $30 \mathrm{~min}$ before incubation with immobilized VN or FN. Although OVCAR-5 cells adhered to VN and FN, CN inhibited adhesion to both ECM proteins dose dependently: $\mathrm{FN} \mathrm{IC}_{50}=10 \mathrm{n} M$, VN $\mathrm{IC}_{50}=1 \mathrm{n} M$ (fig. 1). Although OVCAR-5 adhered to laminin and collagen I, CN was unable to inhibit this adhesion.

\section{Contortrostatin Inhibits OVCAR-5}

\section{Invasion}

In order to find the optimal invasion time for OVCAR-5 cells across Matrigel ${ }^{\mathrm{TM}}$-coated Transwells, several incubation times were tested and a time of $8 \mathrm{~h}$ was chosen for analysis. Under these conditions, CN $(1,000 \mathrm{nM})$ pretreatment of the OVCAR-5 cells was found to inhibit cell migration by about $60 \%$ (fig. 2). $7 \mathrm{E} 3$ (mAb to $\alpha v \beta 3$ ) did not inhibit cell migration, but P1F6 (mAb to $\alpha v \beta 5$ ) at $100 \mathrm{n} M$ inhibited migration to approximately the same extent as $1,000 \mathrm{n} M \mathrm{CN}$.

\section{Animal Model Study}

In order to prevent the occurrence of necrosis that appears in the later stages of ovarian tumor growth, a 4-week treatment schedule was planned, beginning 1 week after the initial tumor injection. In the treatment group (11 animals), CN was administered at the level of $20 \mu \mathrm{g}$ twice per day. Control animals received intraperitoneal saline injections similarly administered. At the conclusion of the study after 4 weeks of treatment, 16 mice ( 8 in each group) were sacrificed. For various reasons, 3 mice in each group were excluded 


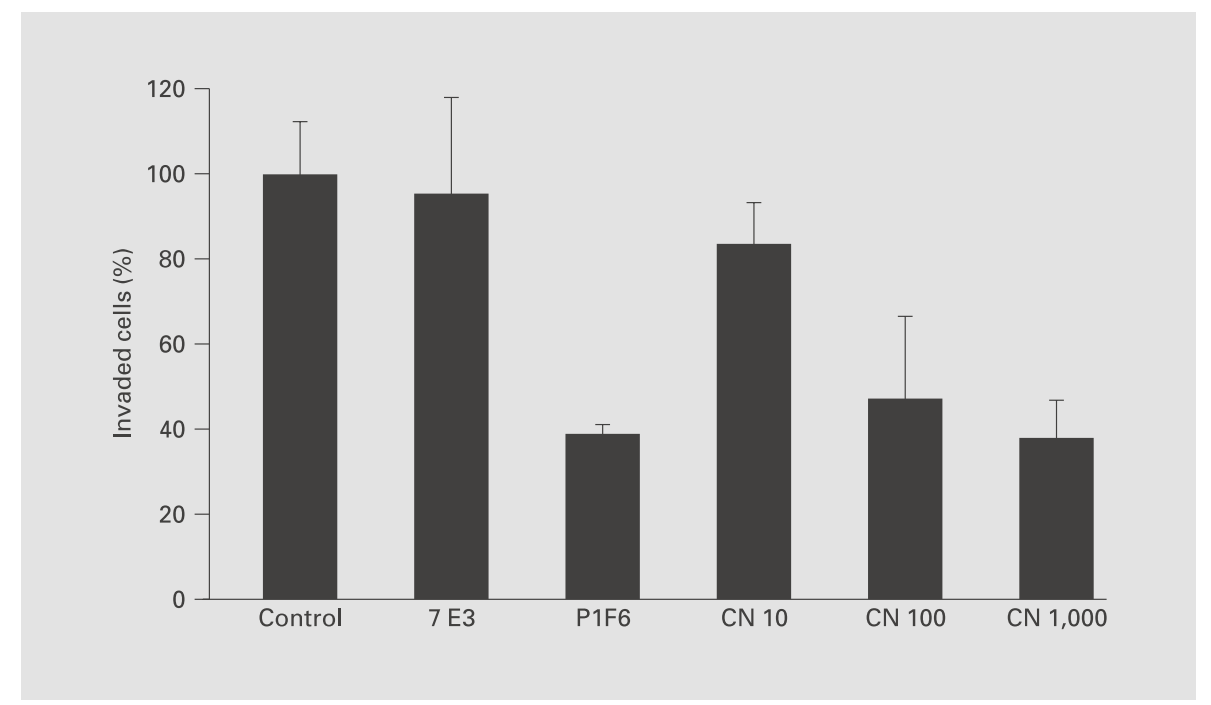

Fig. 2. Inhibition of OVCAR-5 cell invasion through an artificial basement membrane (Matrigel) using a Boyden chamber. Thirty-minute pretreatment of OVCAR-5 cells with varying concentrations of $\mathrm{CN}(0$, 10,100 and $1,000 \mathrm{n} M$ ) inhibited migration across a Matrigel barrier, measured after $8 \mathrm{~h}$. HT1080-conditioned medium served as a chemoattractant in the bottom chamber. Untreated OVCAR-5 cells with HT1080-conditioned medium in the bottom chamber

from the study. A representative mouse was chosen from each group for photography (fig. 3). It is obvious that $\mathrm{CN}$ significantly decreased tumor burden in the $\mathrm{CN}$-treated group. Tissue from 4 representative mice from the remaining mice in each group (control and $\mathrm{CN}$-treated) were formalin fixed for histological examination. Histological sections were stained with antibody against factor-VIII-related antigen as a specific marker of vascular endothelial cells. One of the most remarkable differences between $\mathrm{CN}$-treated and control groups was the complete absence of tumor in various organs of some of the $\mathrm{CN}$ treated animals. Thus, these organs in the animals did not have 'hot spots' of tumor in which microvessel growth could be detected. was used as a positive control, and untreated OVCAR5 cells with SFM in the lower chamber was used as a negative control. Pretreatment of OVCAR-5 cells for 30 min with anti- $\alpha v \beta 3 \mathrm{mAb}$ (7E3) did not inhibit OVCAR-5 invasion significantly, whereas an antiav $\beta 5 \mathrm{mAb}(\mathrm{P} 1 \mathrm{~F} 6)$ at $100 \mathrm{n} M$ inhibited cell invasion by about $60 \%$, approximately the same as that achieved by $1,000 \mathrm{n} M \mathrm{CN}$.

The paucity of tumor in some organ specimens resulted in a zero microvessel count. Moreover, in the $\mathrm{CN}$-treated specimens in which tumor did grow, the microvessel density was dramatically lower than that found in the untreated group (table 1).

\section{Discussion}

Ovarian cancer is usually asymptomatic and not diagnosed until the cancer has spread outside of the ovary. About $70 \%$ of patients with epithelial ovarian cancer present as stage III or IV (advanced disease). Because of this, ovarian cancer has been called a silent killer; it is the leading cause of death from gyneco- 

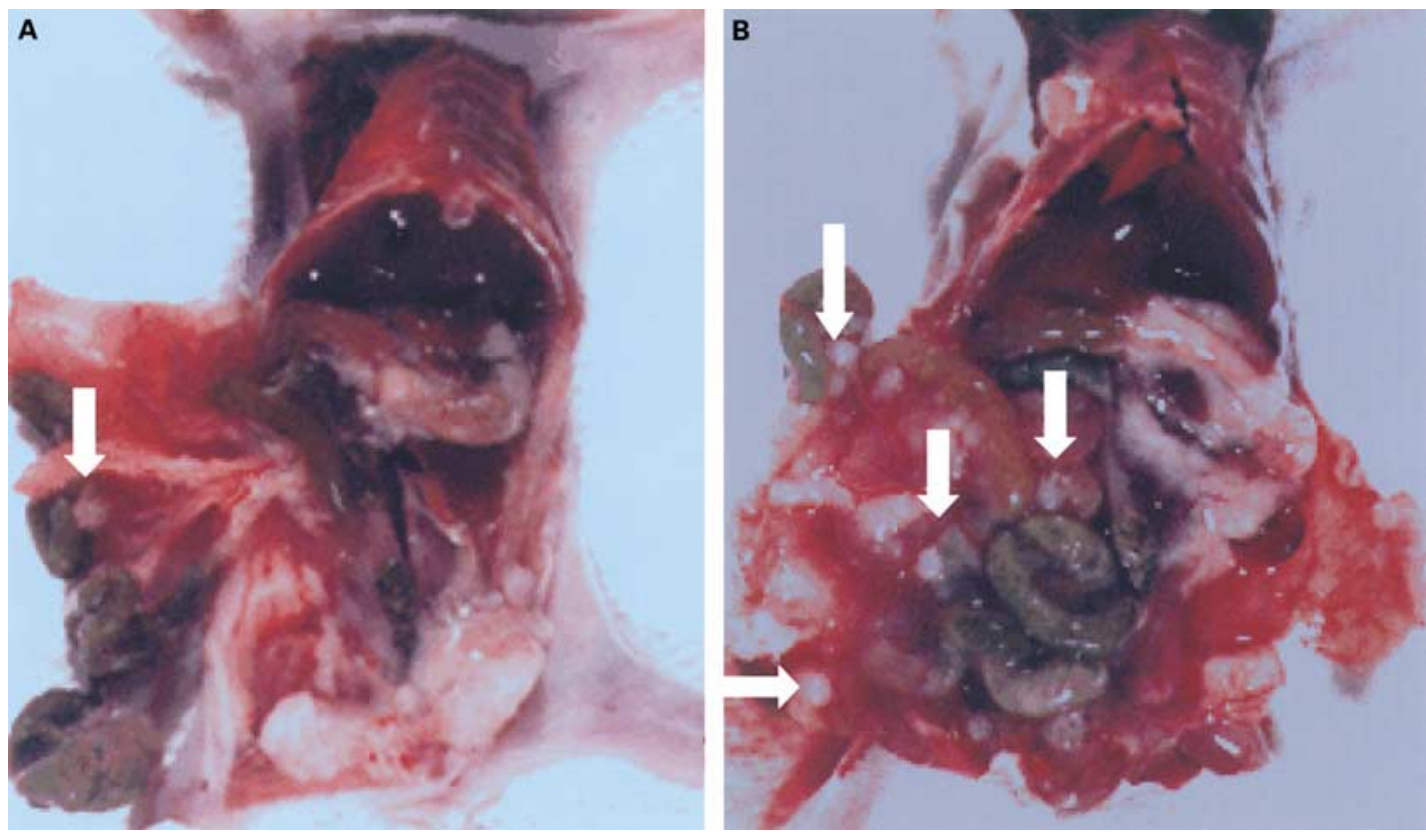

Fig. 3. In vivo model of OVCAR-5 in nude mice. Treated mice $(\mathbf{A})$ showed significantly fewer nodules than control mice $(\mathbf{B})$. OVCAR-5 $\left(1 \times 10^{6}\right.$ cells/mouse $)$ implanted intraperitoneally. Treatment consisted of $20 \mu \mathrm{g}$ of $\mathrm{CN}$ per mouse twice daily for 4 weeks starting 1 week after tumor injection. Arrows point to tumor nodules.

Table 1. Total factor VIII staining area, by treatment and tumor location, determined by image analysis and area measurement (pixels)

\begin{tabular}{lrrrrr}
\hline Treatment & Intestine & Ovary & Spleen & Stomach & Total \\
\hline CN & & & 728.9 & & 728.9 \\
CN & & & $3,128.3$ & & $3,128.3$ \\
CN & & $1,779.3$ & $1,771.7$ & $1,042.8$ & $2,814.5$ \\
CN & & $15,580.8$ & & $1,779.3$ \\
Control (saline) & $49,439.5$ & & & $65,016.3$ \\
Control (saline) & $2,260.2$ & $25,841.5$ & & $10,369.5$ & $10,369.5$ \\
Control (saline) & & & & & $40,222.6$ \\
Control (saline) & $14,540.6$ & 587.2 & $25,094.9$ & & \\
\hline
\end{tabular}

A blank indicates that no tumor developed at this site. 
logical malignancy resulting in 14,800 deaths per year in the United States [19]. It is apparent that present methods of treatment for advanced-stage ovarian cancer are not effective, and novel therapeutic approaches to control growth and spread are needed for this most devastating cancer in women.

The role of angiogenesis in solid tumor growth and dissemination has long been known [20,21], and recently the understanding that tumor growth is angiogenesis-dependent [20] has become a dogma. Folkman [22] proposed a two-compartment tumor model composed of vascular endothelial cell and tumor cell compartments. Angiogenesis appears to be an early event in epithelial ovarian cancer [23] and plays an important role in ovarian cancer growth and dissemination [24]. Angiogenesis has been correlated with prognosis in ovarian cancer patients, a higher vessel count shows a trend to worse overall survival in advanced ovarian cancer [23, 25-27]. Antiangiogenic therapy represents a potentially effective therapy for long-term control of ovarian cancer [28].

The importance of $\mathrm{VN}$ receptors in angiogenesis is well known. It has been shown that an $\mathrm{mAb}$ to integrin $\alpha \mathrm{v} \beta 3$, as well as a cyclic RGD-containing peptide, perturbed angiogenesis and produced regression of a human cancer growing on the chick embryo chorioallantoic membrane [29]. In previous studies, we have shown that $\mathrm{CN}$ effectively blocked adhesion of human umbilical vein endothelial cells to immobilized VN and significantly inhibited invasion of human umbilical vein endothelial cells through a Matrigel barrier [30]. Competitive binding assays and adhesion assays with different integrin antibodies suggested that integrin $\alpha v \beta 3$ is a binding site for $\mathrm{CN}$ on vascular endothelial cells. We conclude that $\mathrm{CN}$ binds to $\alpha \mathrm{v} \beta 3$, and interferes with the anchorage-dependent survival of the vascular endothelial cells and the mobility of the cells. The consequent suppression of angiogenesis is an important component of the antineoplastic activity of $\mathrm{CN}$ [30].

It has also been suggested that integrins play an important role in intraperitoneal dissemination of ovarian cancer [31], as demonstrated by the finding that multiple intraperitoneal injections of an RGD peptide inhibited experimental peritoneal seeding of human ovarian cancer cells in vivo [32]. In vitro studies suggested that $\beta 1$ and $\beta 3$ integrins are important in the interaction of ovarian cancer cells with metastatic sites on the mesothelium [33]. We have shown that OVCAR-5 is $\alpha v \beta 3$ negative; however, $\mathrm{CN}$ is able to block invasion of these cells due to its ability to inhibit the function of $\alpha v \beta 5$ [10]. The role of this integrin $(\alpha v \beta 5)$ in tumor invasion has recently been reported [34]. OVCAR- 5 is $\alpha v \beta 5$ positive, and it is apparently through this integrin that $\mathrm{CN}$ exerts its inhibitory activity on OVCAR-5 adhesion and invasion.

Human ovarian carcinoma cells were found to express integrins at a higher level than normal ovarian cells [35]. Thus, integrins can be targeted in the treatment of ovarian carcinoma. Our in vitro data showing inhibition of ovarian cancer adhesion and invasion have supported the potential for $\mathrm{CN}$ as a possible treatment of this disease. However, an animal model was needed to more closely mimic the interactions between cancer cells and the environment. We chose to use the xenograft model for studying ovarian carcinoma that was established by Hamilton et al. [15]; this model allows both tumor cells and treatment to be administered by intraperitoneal injection. The spread of ovarian cancer was observed grossly in our animal model and the level of angiogenesis was quantitated immunohistochemically (factor VIII staining) to determine whether $\mathrm{CN}$ had an inhibitory effect on angiogenesis. 
In the in vivo studies, image analysis of factor VIII-related antigen detected significantly greater microvessel areas in tissues from control than from $\mathrm{CN}$-treated animals. The findings indicate that the level of angiogenesis was dramatically decreased in $\mathrm{CN}$ treated animals. Moreover, the tumor burden in some of the $\mathrm{CN}$-treated mice was so greatly decreased as to provide no tumor sites for angiogenic study. Thus, the area measurements (pixels) in several of these fields was quantitated to be zero. Gasparini et al. [36] established the term 'hot spot' to describe peripheral areas of the tumor that show greatest microvessel concentration. The use of image analysis for quantitation of microvessel density was found to show less variation than simple manual counts of microvessel density [37]. Although this quantitative method has been used frequently for prognostic purposes $[27,38]$, ours is one of the first studies to use this technology for quantitating experimental data.

$\mathrm{CN}$ is a good candidate for therapeutic use in ovarian cancer because it can inhibit sever- al steps of cancer progression. Unlike other cancers, which progress by the circulatory and lymphatic systems, ovarian cancer is limited to the peritoneum. Intraperitoneal administration of $\mathrm{CN}$ facilitates directing its antitumor activity specifically to tumors localized in the peritoneal cavity. Thus, our investigations have demonstrated that it is feasible to design a delivery system for $\mathrm{CN}$ that targets potential sites of tumor growth.

\section{Acknowledgements}

The research supporting this publication was made possible by funds received from the State of California, Cancer Research Fund, under Interagency Agreement \#97-12013 (University of California contract \#9800924V) with the Department of Health Services, Cancer Research Program. The authors would like to acknowledge the contribution of Dr. Steve Swenson, Department of Biochemistry and Molecular Biology, University of Southern California, Keck School of Medicine, in the preparation of the manuscript.

\section{References}

1 Huang TF, Ouyang C: Action mechanism of the potent platelet aggregation inhibitor from Trimeresurus gramineus snake venom. Thromb Res 1984;33:125-138.

2 Huang TF, Holt JC, Lukasiewicz H, Niewiarowski S: Trigramin. A low molecular weight peptide inhibiting fibrinogen interaction with platelet receptors expressed on glycoprotein IIb-IIIa complex. J Biol Chem 1987; 262:16157-16163.

3 Dennis MS, Henzel WJ, Pitti RM, Lipari MT, Napier MA, Deisher TA, Bunting S, Lazarus RA: Platelet glycoprotein IIb-IIIa protein antagonists from snake venoms: Evidence for a family of platelet-aggregation inhibitors. Proc Natl Acad Sci USA 1990;87:2471-2475.
4 Scarborough RM, Rose JW, Naughton MA, Phillips DR, Nannizzi L, Arfsten A, Campbell AM, Charo IF: Characterization of the integrin specificities isolated from American pit viper venoms. J Biol Chem 1993; 268:1058-1065.

5 McLane MA, Marcinkiewicz C, Vijay-Kumar S, Wierzbicka-Patynowski I, Niewiarowski S: Viper venom disintegrins and related molecules. Proc Soc Exp Biol Med 1998; 219:109-119.

6 Trikha M, Rote WE, Manley PJ, Lucchesi BR, Markland FS: Purification and characterization of platelet aggregation inhibitors from snake venoms. Thromb Res 1994; 73:39-52.
7 Zhou Q, Hu P, Ritter MR, Swenson SD, Argounova S, Epstein AL, Markland FS: Molecular cloning and functional expression of contortrostatin, a homodimeric disintegrin from southern copperhead snake venom. Arch Biochem Biophys 2000; 375:278-288.

8 Trikha M, De Clerck YA, Markland FS: Contortrostatin, a snake venom disintegrin, inhibits beta 1 integrinmediated human metastatic melanoma cell adhesion and blocks experimental metastasis. Cancer Res 1994;54:4993-4998. 
9 Zhou Q, Sherwin RP, Parrish C, Richters V, Groshen SG, Tsao-Wei D, Markland FS: Contortrostatin, a dimeric disintegrin from Agkistrodon contortrix contortrix, inhibits breast cancer progression. Breast Cancer Res Treat 2000;61:249260.

10 Zhou Q, Nakada MT, Brooks PC, Swenson SD, Ritter MR, Argounova S, Arnold C, Markland FS: Contortrostatin, a homodimeric disintegrin, binds to integrin alphavbeta5. Biochem Biophys Res Commun 2000;267:350-355.

11 Hynes RO: Integrins: Versatility, modulation, and signaling in cell adhesion. Cell 1992;69:11-25.

12 Cheresh DA: Structural and biologic properties of integrin-mediated cell adhesion. Clin Lab Med 1992;12: 217-236.

13 Ruoslahti E: Integrins. J Clin Invest 1991;87:1-5.

14 Giancotti FG, Ruoslahti E: Integrin signaling. Science 1999;285:10281032.

15 Hamilton TC, Young RC, Ozols RF: Experimental model systems of ovarian cancer: Applications to the design and evaluation of new treatment approaches. Semin Oncol 1984;11:285-298.

16 Gasparini G, Pozza F, Harris AL: Evaluating the potential usefulness of new prognostic and predictive indicators in node-negative breast cancer patients. J Natl Cancer Inst 1993;85:1206-1219.

17 Seftor RE, Seftor EA, Gehlsen KR, Stetler-Stevenson WG, Brown PD, Ruoslahti E, Hendrix MJ: Role of the alpha $v$ beta 3 integrin in human melanoma cell invasion. Proc Natl Acad Sci USA 1992;89:1557-1561.

18 Filardo EJ, Brooks PC, Deming SL, Damsky C, Cheresh DA: Requirement of the NPXY motif in the integrin beta 3 subunit cytoplasmic tail for melanoma cell migration in vitro and in vivo. J Cell Biol 1995;130: 441-450.

19 Parker SL, Tong T, Bolden S, Wingo PA: Cancer statistics, 1996. CA Cancer J Clin 1996;46:5-27.

20 Folkman J: Tumor angiogenesis: Therapeutic implications. N Engl J Med 1971;285:1182-1186.
21 Folkman J: Editorial: Angiogenesis and breast cancer. J Clin Oncol 1994; 12:441-443.

22 Folkman J: Tumor angiogenesis and tissue factor. Nat Med 1996;2:167168.

23 Nakanishi Y, Kodama J, Yoshinouchi M, Tokumo K, Kamimura S, Okuda H, Kudo T: The expression of vascular endothelial growth factor and transforming growth factor-beta associates with angiogenesis in epithelial ovarian cancer. Int J Gynecol Path 1997;16:256-262.

24 Barcz E, Sommer E, Sokolnicka I, Gawrychowski K, RoszkowskaPurska K, Janik P, Skopinska-Rozewska E: The influence of theobromine on angiogenic activity and proangiogenic cytokines production of human ovarian cancer cells. Oncol Rep 1998;5:517-520.

25 Abu-Jawdeh GM, Faix JD, Niloff J, Tognazzi K, Manseau E, Dvorak HF, Brown LF: Strong expression of vascular permeability factor (vascular endothelial growth factor) and its receptors in ovarian borderline and malignant neoplasms. Lab Invest 1996;74:1105-1115.

26 Abulafia O, Triest WE, Sherer DM: Angiogenesis in primary and metastatic epithelial ovarian carcinoma. Am J Obstet Gynecol 1997;177: 541-547.

27 Schoell WM, Pieber D, Reich O, Lahousen M, Janicek M, Guecer F, Winter R: Tumor angiogenesis as a prognostic factor in ovarian carcinoma: Quantification of endothelial immunoreactivity by image analysis. Cancer 1997;80:2257-2262.

28 Pluda JM: Tumor-associated angiogenesis: Mechanisms, clinical implications, and therapeutic strategies. Semin Oncol 1997;24:203-218.

29 Brooks PC, Montgomery AM, Rosenfeld M, Reisfeld RA, Hu T, Klier $\mathrm{G}$, Cheresh DA: Integrin alpha $\mathrm{v}$ beta 3 antagonists promote tumor regression by inducing apoptosis of angiogenic blood vessels. Cell 1994; 79:1157-1164.

30 Zhou Q, Nakada MT, Arnold C, Markland FS: Contortrostatin, a dimeric disintegrin from Agkistrodon contortrix contortrix, inhibits angiogenesis. Angiogenesis 1999;3:259269.
31 Buczek-Thomas JA, Chen N, Hasan $\mathrm{T}$ : Integrin-mediated adhesion and signalling in ovarian cancer cells. Cellular Signal 1998;10:55-63.

32 Yamamoto K, Murae M, Yasuda M: RGD-containing peptides inhibit experimental peritoneal seeding of human ovarian cancer cells. Nippon Sanka Fujinka Gakkai Zasshi 1991; 43:1687-1692.

33 Gardner MJ, Jones LM, Catterall JB, Turner GA: Expression of cell adhesion molecules on ovarian tumour cell lines and mesothelial cells, in relation to ovarian cancer metastasis. Cancer Lett 1995;91:229234.

34 Brooks PC, Klemke RL, Schon S, Lewis JM, Schwartz MA, Cheresh DA: Insulin-like growth factor receptor cooperates with integrin alpha $\mathrm{v}$ beta 5 to promote tumor cell dissemination in vivo. J Clin Invest 1997;99:1390-1398.

35 Bartolazzi A, Kaczmarek J, Nicolo G, Risso AM, Tarone G, Rossino P, Defilippi P, Castellani P: Localization of the alpha 3 beta 1 integrin in some common epithelial tumors of the ovary and in normal equivalents. Anticancer Res 1993;13:111.

36 Gasparini G, Brooks PC, Biganzoli E, Vermeulen PB, Bonoldi E, Dirix LY, Ranieri G, Miceli R, Cheresh DA: Vascular integrin alpha(v)beta3: A new prognostic indicator in breast cancer. Clin Cancer Res 1998;4:2625-2634.

37 Wild R, Ramakrishnan S, Sedgewick J, Griffioen AW: Quantitative assessment of angiogenesis and tumor vessel architecture by computer-assisted digital image analysis: Effects of VEGF-toxin conjugate on tumor microvessel density. Microvasc $R$ es 2000;59:368-376.

38 Charpin C, Devictor B, Bergeret D, Andrac L, Boulat J, Horschowski N, Lavaut MN, Piana L: CD31 quantitative immunocytochemical assays in breast carcinomas. Correlation with current prognostic factors. Am J Clin Pathol 1995;103:443-448. 